\title{
Microbiological and Thin-Layer Chromatographic Identification of Benzylpenicillin and Ampicillin in Animal Body
}

\author{
Haruo YOSHIMURA, Osamu ITOH and Shoichi YONEZAWA \\ National Veterinary Assay Laboratory, 1-15-1 Tokura, \\ Kokubunji-shi, Tokyo 185
}

(Received for publication March 26, 1981)

\begin{abstract}
Benzylpenicillin (PG-G) and ampicillin (AB-PC) were administered intramuscularly to pigs and calves. An attempt was made to identify these penicillins qualitatively in tissues and urine collected from the animals after slaughter. The kidney, liver and muscle were homogenized into fourfold dilutions. The diameter of an inhibition zone produced by each dilution was determined on Micrococcus luteus ATCC 9341 and Bacillus subtilis ATCC 6633 plates at $\mathrm{pH} 6.0$ and 8.0 . The urine was diluted up to 625 -fold. Thinlayer chromatographic identification was performed for only tissue and urine samples characterized by the largest inhibition zone that was observed on $M$. luteus plate and inactivated by the addition of penicillinase. Next, a sample extracted with methanol was spotted on a silica gel plate, which was then developed in ethyl acetate-methanol-water $(6: 2: 1)$. Rf values were determined by bioautography with $M$. luteus as the test organism. They were about 2 times as high in animals given PC-G as in those given AB-PC. They coincided closely with those of reference antibiotic solutions. Thus, it seems likely that PC-G and AB-PC residues may be identified in slaughtered animals by thin-layer chromatography with the spot volume of 10 and/or $30 \mu l$ on the basis of inhibition zones produced on $M$. luteus plate. It was recommended that chromatography should be performed on extracts from the medulla rather than cortex of the kidney, which had been proved to contain penicillins.
\end{abstract}

The use of antibiotics for the treatment and prevention of infectious diseases in animals may have created a variety of problems involving a hazard to the consumer. Much attention has been paid to allergic reactions in sensitized individuals and the development of resistant pathogens in man and animals [6].

In some countries, a detection of antibiotic residues has been conducted qualitatively in slaughtered animals by official methods, such as Micrococcus luteus (Sarcina lutea) kidney test and general inhibitor test $[12,18,21]$. On the other hand, not only muscle but also at least kidney and liver have always been surveyed in slaughtered animals for antibiotic residues [3, 15,
20, 22]. Other surveys have been carried out on urine $[7,17,19]$, into which certain antibiotics might have been excreted for a long period and at high concentrations. There is a possibility, however, that the antibacterial activities detected may have been originated from non-specific inhibitory substances, such as lysozyme and lactic acid, formed in a few tissues and urine from time to time $[4,14,16]$. Then, it is recommended to improve some procedures by which antibiotic residues can be identified in slaughtered animals in more detail.

In literature on antibiotic residues in slaughtered animals, the presence of penicillin was confirmed by using penicillinase $[7,17,23]$. However, in addition to benzyl- 
Table 1. Test protocol

\begin{tabular}{|c|c|c|c|c|c|}
\hline $\begin{array}{l}\text { Animal } \\
\text { No. }\end{array}$ & $\begin{array}{l}\text { Species } \\
\text { and sex }\end{array}$ & $\begin{array}{l}\text { Approx. body } \\
\text { weight in } \mathrm{kg}\end{array}$ & $\begin{array}{l}\text { Antibiotic } \\
\text { administered }\end{array}$ & $\begin{array}{l}\text { Dose in } \\
\text { IU or } \mathrm{mg}\end{array}$ & $\begin{array}{l}\text { Time in hours } \\
\text { until slaughter }\end{array}$ \\
\hline 2 & calf $(\hat{0})$ & 200 & \multirow{5}{*}{$\begin{array}{l}\text { Benzyl- } \\
\text { penicillin }{ }^{1)}\end{array}$} & $1,500,000$ & 2 \\
\hline 4 & calf $(\hat{O})$ & 250 & & $3,000,000$ & 12 \\
\hline 28 & calf $(\hat{O})$ & 250 & & $3,000,000$ & 24 \\
\hline 6 & pig $(\hat{\varnothing})$ & 50 & & 600,000 & 6 \\
\hline 18 & pig (우) & 50 & & 900,000 & 6 \\
\hline 1 & calf $(\hat{O})$ & 200 & \multirow{4}{*}{ Ampicillin 2$)$} & 1,000 & 2 \\
\hline 3 & calf (S) & 300 & & 1,500 & 12 \\
\hline 5 & pig $(\hat{\&})$ & 50 & & 400 & 6 \\
\hline 17 & pig (우) & 50 & & 600 & 6 \\
\hline 11 & calf $(\hat{b})$ & 250 & \multirow{2}{*}{ control } & & \\
\hline 12 & pig (우) & 50 & & & \\
\hline
\end{tabular}

1) Procaine penicillin in aqueous suspension (Meiii) for veterinary use, containing $300,000 \mathrm{lU}$ of benzylpenicillin $/ \mathrm{ml}$.

2) Vicillin sol-200 for veterinary use (Meiji), containing $200 \mathrm{mg}$ of ampicillin $/ \mathrm{ml}$.

penicillin (PG-G) utilized since a long time ago, ampicillin (AB-PC) is now widely available for domestic animals. It is inactivated in the same manner as PC-G by the addition of penicillinase. The present paper deals with a procedure to identify PC-G and AB-PC contained in the kidney, liver, muscle and urine of animals given commercial products containing these antibiotics.

\section{Materials and Methods}

\section{Animals}

Six Holstein calves weighing from 200 to $300 \mathrm{~kg}$ and 5 Yorkshire pigs weighing approximately $50 \mathrm{~kg}$ were used. Of them, 3 calves (Nos. 2, 4 and 28) and 2 pigs (Nos. 6 and 18) were given a single intramuscular administration of an aqueous suspension of PC-G procaine. Two calves (Nos. 1 and 3) and 2 pigs (Nos. 5 and 17) were injected with AB-PG in oily suspension by the same route. After the antibiotics were administered, the animals were slaughtered at various intervals as scheduled in the test protocol (Table 1). The remaining 2 animals served as controls.

The kidney, liver, muscle and urine were collected from each animal and kept in frozen state until use.

2. Diameter of inhibition zones on $M$. luteus and Bacillus subtilis

By using antibiotic medium No. 1 (Difco) ad- justed to $\mathrm{pH} 6.0$ and 8.0 with hydrochloric acid or sodium hydroxide, agar plates were made to screen samples containing antibacterial activities. The plates were prepared in such manner as described below.

Ten $\mathrm{m} l$ of medium at each $\mathrm{pH}$ was poured in Petri dishes $(10 \mathrm{~cm}$ in diameter) as the base layer. When solidified, $4 \mathrm{~m} l$ of the same medium previously inoculated with $M$. luteus ATCC 9341 or $B$. subtilis ATCC 6633 was overlaid as the seed layer. In the seed layer, $M$. luteus was added in a concentration of $0.5 \%$, by using fresh cultures propagated in nutrient broth at $37^{\circ} \mathrm{C}$ for 18 hours. B. subtilis was added to give a bacterial count of $1.2 \times 10^{4} / \mathrm{m} l$, by using a spore suspension stored in a refrigerator.

A tissue sample (usually $5 \mathrm{~g}$ ) was homogenized fourfold with distilled water and filled steel cups ( $8 \mathrm{~mm}$ in diameter) placed on $M$. luteus and $B$. subtilis plates at $\mathrm{pH} 6.0$ and 8.0. Besides, a drop of penicillinase was added to one of the tissue homogenates, which filled steel cups placed on the $M$. luteus plate. After allowed to stand at room temperature for 1 hour, all the plates were incubated overnight at $37^{\circ} \mathrm{C}$. The diameters of inhibition zones produced were measured and averaged. Urine samples were serially diluted with distilled water up to 625 -fold with a dilution of 1:5. The diameters of inhibition zones produced on the plates were determined. By these procedures, it was possible to screen the tissue and urine samples containing more than 0.1 and $0.02 \mu \mathrm{g}$ or $\mathrm{IU} / \mathrm{g}$ of the antibiotic, respectively. Thin-layer chromatographic identification was carried out only on samples characterized by the largest inhibition zone 
that was observed on the $M$. luteus plate and lost by the addition of penicillinase.

3. Thin-layer chromatographic identification

Tissues were homogenized threefold with methanol and centrifuged at $3000 \mathrm{xpm}$ for $10 \mathrm{~min}$ [5]. The resultant supernatant was regarded as the solution to be chromatographed. Aliquots of $10 \mu l$ of this solution were spotted to the origin of the silica gel plate (spot film for thin-layer chromatography (TLC), $20 \times 20 \mathrm{~cm}$, TOKYO Kasei), along with the same volume of the pure reference antibotic solu. tions dissolved in methanol in concentrations of $0.5 \mathrm{IU} / \mathrm{m} l$ for PG-G and $0.2 \mu \mathrm{g} / \mathrm{ml}$ for AB-PC. After allowed to dry, each plate was developed in ethyl acetate-methanol-water (6:2:1) until the solvent front reached approximately $15 \mathrm{~cm}$ from the starting line [9]. The plate was dried by the aid of a fan to remove the excess solvent and placed on the surface of the agar medium previously solidified in an aluminum plate $(20.5 \times 20.5 \mathrm{~cm})$, on which was then poured $40 \mathrm{~m} l$ of antibiotic medium No. 1 ( $\mathrm{pH}$ 6.0) inoculated with $M$. luteus. After overnight incubation at $37^{\circ} \mathrm{C}$, Rf values were determined from the location of the area of inhibited bacterial growth on chromatograms. The chromatograms could be easily seen by adding $4 \%$ aqueous solution of 2,3,5,-triphenyl-tetrazolium chloride.

When no area of inhibited bacterial growth was observed on the chromatograms by the method mentioned above, the solution was chromatographed once again with a spot volume of $30 \mu l$. In this case, the concentrations of the reference antibiotic solutions were $0.2 \mathrm{IU} / \mathrm{m} l$ for $\mathrm{PC}-\mathrm{G}$ and $0.1 \mu \mathrm{g} / \mathrm{m} l$ for AB-PC.

Urine samples were diluted with methanol to such concentrations as corresponding to the diameters of inhibition zones ranging from 25 to $30 \mathrm{~mm}$ which might be produced on $M$. luteus plated if diluted with distilled water and determined. A preliminary experiment indicated that the area of inhibited bacterial growth could easily be obtained and $R f$ values read by the use of urine samples diluted up to such concentrations as exhibiting antibacterial activities. Identification was carried out in the same manner as that conducted on tissue samples.

4. Qualitative assay of antibacterial activities in tissues and urine

Pieces about $1 \mathrm{~cm}$ square were cut from the tissue sample in frozen state and placed on $M$. luteus plated at pH 6.0 and 8.0. Paper discs were soaked into the urine before use. The antibacterial activities were detected qualitatively after incubation at $37^{\circ} \mathrm{C}$ for 18 hours. A sample was regarded as positive when it induced an inhibition zone
$1 \mathrm{~mm}$ or more.

5. Antibiotic concentrations in renal tissues

An attempt was made to compare the antibiotic concentration between cortex and medulla of the kidney by a hole-plate method with a rectangular large plate $(30 \times 30 \mathrm{~cm})$ modified from the method of Bennett et al. [2]. As the base layer was used $200 \mathrm{~m} l$ of No. 5 medium ( $\mathrm{pH} \mathrm{6.0)}$ prepared in the same manner as prescribed in the Minmun Requirements for Antibiotics for Animal Use [10]. As the seed layer was used $100 \mathrm{~m} l$ of the same medium inoculated with $M$. luteus.

The cortex and medulla were separately homogenized fourfold with $0.1 \mathrm{M}$ phosphate buffer $(\mathrm{pH}$ 6.0 ) in a glass mortar. The resulting supernatant was pipetted in holes $8 \mathrm{~mm}$ in diameter on the agar plate in $0.1 \mathrm{~m} l$ amounts. The plate was cut with a specially designed punch. The reference antibiotics used to prepare standard curves were dissolved in phosphate buffer. The threshold sensitivity of each antibiotic was $0.1 \mathrm{IU}$ or $\mu \mathrm{g} / \mathrm{g}$.

\section{Results}

1. Identification of penicillins in tissues Table 2 shows the diameters of inhibition zones produced by tissue samples on $M$. luteus and B. subtilis plates, as well as $\mathrm{Rf}$ values obtained by TLC.

Regarding the test organisms, $M$. luteus was more inhibited than $B$. subtilis. Inhibition zones were a little larger on plates at $\mathrm{pH} 6.0$ than on those at $\mathrm{pH} 8.0$ for almost all the samples. In each animal, inhibition zones produced by the muscular tissue were apparently smaller than those by the other 2 tissues. No inhibition zone was observed on the $M$. luteus plate for any sample to which had been added penicillinase.

Examination of chromatograms spotted with $10 \mu l$ revealed that $\mathrm{Rf}$ values were $0.41-0.44$ and $0.19-0.20$ in animals given PC-G and AB-PC, respectively, and that they coincided well with those of the reference antibiotic solutions. A similar result was obtained with a spot volume of $30 \mu l$.

In some samples (muscles of Nos. 2 and 18, livers of Nos. 18 and 3, and kidney of No. 17) their homogenates produced in- 
Table 2. Diameter of inhibition zones on M. luteus and B. subtilis plates, and $\mathrm{RF}$ values in chromatography on tissue samples

\begin{tabular}{|c|c|c|c|c|c|c|c|}
\hline \multirow{3}{*}{$\begin{array}{l}\text { Animal } \\
\text { No. }\end{array}$} & \multirow{3}{*}{ Tissue } & \multicolumn{4}{|c|}{ Inhibition zone (in $\mathrm{mm}$ ) } & \multicolumn{2}{|c|}{ Rf } \\
\hline & & \multicolumn{2}{|c|}{ M. Iuteus } & \multicolumn{2}{|c|}{ B. subtilis } & \multicolumn{2}{|c|}{ Spot volume } \\
\hline & & $\mathrm{pH} 6.0$ & $\mathrm{pH} 8.0$ & pH 6.0 & $\mathrm{pH} 8.0$ & $10 \mu l$ & $30 \mu l$ \\
\hline \multirow{3}{*}{2} & Kidney & 21.5 & 20.5 & 15.3 & 14.8 & 0.41 & ND \\
\hline & Liver & 21.0 & 18.5 & $N Z$ & $N Z$ & 0.42 & ND \\
\hline & Muscle & 17.8 & 17.5 & NZ & $\mathrm{NZ}$ & no & 0.34 \\
\hline \multirow{3}{*}{4} & Kidney & 34.5 & 34.5 & 25.0 & 25.0 & 0.43 & ND \\
\hline & Liver & 35.8 & 34.3 & 24.5 & 24.3 & 0.44 & ND \\
\hline & Muscle & 9.5 & 9.5 & $N Z$ & $N Z$ & no & no \\
\hline \multirow{3}{*}{28} & Kidney & 22.6 & 21.8 & 18.3 & 17.3 & 0.41 & ND \\
\hline & Liver & 31.3 & 30.3 & 25.5 & 24.1 & 0.44 & ND \\
\hline & Muscle & $N Z$ & $N Z$ & NZ & $N Z$ & \multicolumn{2}{|c|}{ ND } \\
\hline \multirow{3}{*}{6} & Kidney & 17.3 & 16.3 & $N Z$ & $N Z$ & 0.44 & ND \\
\hline & Liver & 8.5 & $N Z$ & $N Z$ & $N Z$ & no & no \\
\hline & Muscle & NZ & $N Z$ & $N Z$ & $N Z$ & \multicolumn{2}{|c|}{ ND } \\
\hline \multirow{3}{*}{18} & Kidney & 22.4 & 20.5 & 18.3 & 15.1 & 0.44 & ND \\
\hline & Liver & 18.5 & 17.5 & NZ & $N Z$ & no & 0.32 \\
\hline & Muscle & 13.3 & 12.3 & $\mathrm{NZ}$ & $\mathrm{NZ}$ & no & 0.35 \\
\hline \multirow{3}{*}{1} & Kidney & 28.5 & 26.5 & 20.5 & 17.5 & 0.20 & ND \\
\hline & Liver & 25.1 & 21.5 & $N Z$ & $N Z$ & 0.19 & ND \\
\hline & Muscle & 20.8 & 17.3 & $N Z$ & NZ & 0.18 & ND \\
\hline \multirow{3}{*}{3} & Kidney & 18.8 & 16.3 & $N Z$ & $N Z$ & 0.20 & ND \\
\hline & Liver & 15.6 & 13.2 & $N Z$ & $N Z$ & no & 0.14 \\
\hline & Muscle & $N Z$ & $N Z$ & $N Z$ & $N Z$ & \multicolumn{2}{|c|}{ ND } \\
\hline \multirow{3}{*}{5} & Kidney & $N Z$ & $N Z$ & $N Z$ & $N Z$ & \multicolumn{2}{|c|}{ ND } \\
\hline & Liver & $N Z$ & $N Z$ & $N Z$ & $N Z$ & \multicolumn{2}{|c|}{ ND } \\
\hline & Muscle & NZ & $\mathrm{NZ}$ & $\mathrm{NZ}$ & $\mathrm{NZ}$ & \multicolumn{2}{|c|}{ ND } \\
\hline \multirow{3}{*}{17} & Kidney & 17.3 & 17.0 & $N Z$ & $N Z$ & no & 0.14 \\
\hline & Liver & 12.5 & 13.0 & $\mathrm{NZ}$ & $N Z$ & no & no \\
\hline & Muscle & $N Z$ & $N Z$ & $N Z$ & $N Z$ & \multicolumn{2}{|c|}{ ND } \\
\hline
\end{tabular}

NZ: No zone formed. ND: Not done. no: No area of inhibited bacterial growth on the chromatogram.

Rf values by reference antibiotic solutions spotted with $10 \mu l$ were 0.43 and 0.21 , and those spotted with $30 \mu l 0.35$ and 0.17 for $P C-G$ and $A B-P C$, respectively.

hibition zones less than $20 \mathrm{~mm}$ in width on the $M$. luteus plate, and there were no areas of inhibited bacterial growth on their chromatograms spotted with $10 \mu l$. Areas of inhibited bacterial growth became visible on their chromatograms when the spot volume was increased to $30 \mu 1$. In other samples (muscle of No. 4 and livers of Nos. 6 and 17) their homogenates produced much smaller inhibition zones on the $M$. luteus plate than those mentioned above, and no areas of inhibited bacterial growth were observed on their chromatograms even with a spot volume of $30 \mu l$.

The area of inhibited bacterial growth on the chromatogram was always round or oval in shape for all the samples, except the muscle of a calf (No. 1) given AB-PC, that exhibited tailing, as shown in Fig. 1.

2. Identification of penicillins in urine 


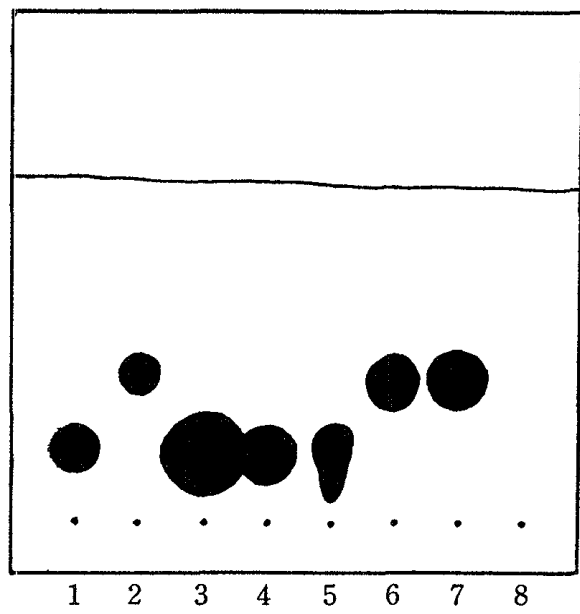

Fig. 1. TLC pattern of inhibited baterial growth on silica gel plate spotted with $10 \mu l$.

1, AB-PC standard; 2, PC-G standard; 3-5, Kidney, liver and muscle of calf No. 1; 6-8, Kidney, liver and muscle of calf No. 2.

Since the concentration of penicillin excreted in urine was very high, it gave rise to an inhibition zone much larger than that produced by a tissue sample. Some urine samples produced inhibition zones $30 \mathrm{~mm}$ or so in diameter, even if diluted 625 times with distilled water (Table 3).
PG-G and AB-PG excreted in a urine sample were easily identified by TLC with a spot volume of $10 \mu 1$ when the sample was diluted 20-500 times with methanol. No tailing or metabolites were observed in any urine sample.

3. Qualitative assay

In animals given PC-G, positive results were obtained from all the samples, including 2 muscle samples (Nos. 6 and 28) the homogenates of which failed to produce an inhibition zone for any test organism (Table 4). When animals were administered with AB-PC, the kidney was found to be positive in three, and the muscle in one of them. All the samples collected from control animals were negative for this assay.

4. Antibiotic concentration in kidney

Antibiotic concentrations were compared between the cortex and medulla of the kidney. The results obtained are shown in Table 5. They were several times as high in the medulla as in the cortex, regardless of the type of antibiotics administered.

Table 3. Diameter of inhibition zones on $M$. luteus and B. subtilis plates, and Rf values in chromatography on urine samples

\begin{tabular}{|c|c|c|c|c|c|c|}
\hline \multirow{3}{*}{$\begin{array}{l}\text { Animal } \\
\text { No. }\end{array}$} & \multicolumn{4}{|c|}{ Inhibition zone (in $\mathrm{mm}$ ) } & \multicolumn{2}{|c|}{$\mathrm{Rf}$} \\
\hline & \multicolumn{2}{|c|}{ M. Iuteus } & \multicolumn{2}{|c|}{ B. subrilis } & \multirow{2}{*}{\multicolumn{2}{|c|}{$\begin{array}{l}\text { Spot volume of } \\
\qquad 10 \mu l\end{array}$}} \\
\hline & \multirow{2}{*}{$\frac{\mathrm{pH} 6.0}{29.0}$} & \multirow{2}{*}{$\frac{\mathrm{pH} 8.0}{28.3}$} & \multirow{2}{*}{$\frac{\mathrm{pH} 6.0}{22.5}$} & \multirow{2}{*}{$\frac{\mathrm{pH} 8.0}{20.5}$} & & \\
\hline 2 & & & & & 0.40 & $(500)$ \\
\hline 4 & 31.3 & 30.5 & 24.5 & 22.8 & 0.39 & $(500)$ \\
\hline 28 & \multicolumn{2}{|c|}{ ND } & \multicolumn{2}{|c|}{ ND } & \multicolumn{2}{|c|}{ ND } \\
\hline 6 & 25.5 & 24.3 & 19.3 & 16.0 & 0.38 & $(200)$ \\
\hline 18 & 30.0 & 29.0 & 23.5 & 21.3 & 0.40 & $(200)$ \\
\hline 1 & 19.0 & 15.0 & $N Z$ & $N Z$ & 0.25 & $(200)$ \\
\hline 3 & 26.5 & 24.5 & 18.0 & 15.8 & 0.26 & $(200)$ \\
\hline 5 & 15.0 & 12.5 & $N Z$ & $N Z$ & 0.29 & $(50)$ \\
\hline 17 & 14.5 & 15.0 & $\mathrm{NZ}$ & NZ & 0.26 & $(20)$ \\
\hline
\end{tabular}

See the footnote of Table 2 .

* Presented only inhibition zones produced by urine samples that were diluted 625-fold.

$\mathrm{Rf}$ values by reference antibiotic solutions were 0.39 and 0.27 for $P C-G$ and $A B-P C$, respectively.

In parentheses is shown the dilution factory by which urine samples dissolved in methanol were chromatographed. 
Table 4. Qualitative assay of antibacterial activities in tissues and urine, using $M$. luteus plates at $\mathrm{pH} 6.0$ and 8.0

\begin{tabular}{|c|c|c|c|c|c|c|c|c|}
\hline \multirow{2}{*}{$\begin{array}{c}\text { Animal } \\
\text { No. }\end{array}$} & \multicolumn{2}{|c|}{ Kidney } & \multicolumn{2}{|c|}{ Liver } & \multicolumn{2}{|c|}{ Muscle } & \multicolumn{2}{|c|}{ Urine } \\
\hline & $\mathrm{pH} 6.0$ & $\mathrm{pH} 8.0$ & $\mathrm{pH} 6.0$ & $\mathrm{pH} 8.0$ & $\mathrm{pH} 6.0$ & $\mathrm{pH} 8.0$ & $\mathrm{pH} 6.0$ & $\mathrm{pH} 8.0$ \\
\hline 2 & + & + & + & + & + & + & + & + \\
\hline 4 & + & + & + & + & + & + & + & + \\
\hline 28 & + & + & + & + & + & + & \multicolumn{2}{|c|}{ ND } \\
\hline 6 & + & + & + & + & + & + & + & + \\
\hline 18 & + & + & + & + & + & + & + & + \\
\hline 1 & + & + & + & + & + & + & + & + \\
\hline 3 & $t$ & + & + & + & - & - & + & + \\
\hline 5 & - & - & + & + & - & - & + & + \\
\hline 17 & + & + & + & + & - & - & + & + \\
\hline
\end{tabular}

ND: Not done.

Table 5. Antibiotic concentrations in cortex and medulla of kidney

\begin{tabular}{rrrrrrrr}
\hline \multicolumn{2}{c}{ Benzylpenicillin $(\mathrm{IU} / \mathrm{g})$} & & \multicolumn{3}{c}{ Ampicillin $(\mu \mathrm{g} / \mathrm{g})$} \\
\cline { 1 - 2 } Animal No. & Cortex & Medulla & & Animal No. & Cortex & Medulia \\
\hline 2 & 1.85 & 10.25 & & 1 & 1.75 & 9.75 \\
4 & 4.80 & 25.00 & & 3 & 0.37 & 1.05 \\
26 & 1.83 & 5.50 & & 5 & 0 & 0 \\
6 & 0.96 & 3.95 & & 17 & 0.40 & 0.60 \\
18 & 3.00 & 8.50 & & & & \\
\hline
\end{tabular}

\section{Discussion}

In their studies on the distribution of penicillins in tissues and body fluids, Rollins et al. [13], Mashimo et al. [9], and Tittiger et al. [17] used $M$. luteus as the most sensitive and reliable test organism. On the one hand, surveys have been done on antibiotic residues in slaughtered animals by the microbiological methods with agar plates at $\mathrm{pH} 6.0$ and 8.0 inoculated with such highly sensitive test organisms as $M$. luteus and $B$. subtilis $[1,3,7,8,12,15$, $17-19,21,22]$. On the other hand, Murakawa et al. [11], Higuchi et al. [5], and Mashimo et al. [9] used TLC in their attempts to separate and determine penicillins in tissues and body fluids. In the present investigation to identify PG-G and AB-PG, TLC was applied to tissue and urine samples which had previously been screened by using agar plates at different $\mathrm{pH}$ values inoculated with $M$. luteus and B. subtilis.

The presence of penicillins in tissue and urine samples was demonstrated by the formation of inhibition zones on agar plates, where these zone were larger for $M$. luteus than for B. subtilis, and a little larger at pH 6.0 than at pH 8.0 or of almost the same size at both $\mathrm{pH}$ values $[8,13,15,17,19]$. Some workers $[7,17,23]$ employed penicillinase, an enzyme inactivating penicillin.

In this study, PG-G and AB-PG in tissue and urine samples screened with agar plates were shown to be identifiable by TLC with a spot volume of 10 and/or $30 \mu l$. From the results of the present study, it seems possible to identify these penicillins contained in tissue samples with a spot volume of $10 \mu l$ when the homogenates of these samples produce inhibition zone $20 \mathrm{~mm}$ or 
more in width on $M$. luteus plates. The antibiotics contained in the muscular or hepatic tissue from some animals (Nos. 4, 6, and 17) could not be identified even with a spot volume of $30 \mu l$, although the homogenate of such tissue produced inhibition zones on $M$. luteus plates.

No inhibition zones were produced on any plate by the homogenate of the muscular tissue from 2 animals (Nos. 6 and 28) which were positive for the qualitative assay. Thus, the residual antibiotics in meat are shown to be easily detectable by the qualitative assay, although their kind remains unknown. It is possible, however, to guess the kind of penicillin in meat if identification by TLC is successful in the kidney or liver of the same subject. This is because antibiotics are known to be distributed more densely in these excretory organs than in the muscle, and because a close correlation is maintained in concentration among the organs and tissues at various sites, except aminoglycoside antibiotics remaining in the kidney prolonged. In slaughtered animals, the residues of penicillins will be anticipated in meat by examining the kidney, liver, or urine occasionally in the same subject.

As listed in Table 5, penicillin concentrations were apparently higher in the medulla than in the cortex of the kidney. This result is in accord with the finding of Rollins et al. [13] who gave the product to cows by the intramammary route. From all these results it is concluded that the use of the medulla is preferred for the identifcation of penicillins in the kidney by TLC.

\section{References}

[1] Beck, Gg., and Mantel, Th. (1972). Der biologische Hemmstofftest: Ein Weg zur Klärung des Rückstandsproblems in Fleisch. Fleischwirtschaft 52, 1605-1609.

[2] Bennet, J. V., Brodie, J. L., Bonner, E. J., and
Kirby, M. M. (1966). Simplified, accurate method for antibiotic assay of clinical specimens. Appl. Microbiol. 14, 170-177.

[3] Bentler, W., and Zettl, K. (1973). Die Anwendbarkeit des "allgemeinen HemmstoffTestes" (AH-Test) bei der Untersuchung auf mikrobiologisch aktive Rückstände in Fleisch und Organen. Dtsch. Tieraerztl. Wochenschr. 80, 35-38 \& 62-63.

[4] Heiner, H. H., van der Wail, G., and Brehner, H. (1976). Lysozym-Ursache von unspezifischen Reaktionen im mikrobiologischen Hemmstofftest. Arch. Lebensm-hyg. 27, 55-60.

[5] Higuchi, S., Yakushiji, M., Eto, K., and Shigematsu, S. (1971). Differential assay and clinical application of ampicillin-cloxacillin. Jpn. J. Antibiot. 24, 1-7.

[6] Huber, W. G. (1971). The impact of antibiotic drugs and their residues. In advances in Veterinary Science and Comparative Medicine 15, 101-132. Academic Press, New York \& London.

[7] Huber, W. G., Carlson, M. B., and Lepper, M. H. (1969). Penicillin and antimicrobial residues in domestic animals at slaughter. $J$. Am. Vet. Med. Assoc. 154, 1590-1595.

[8] Langner, H. J., and Teufel, U. (1973). Der chemische und mikrobiologische Nachweis von Antibiotika. 4. Die qualitative mikrobiologische Bestimmung verschiedener Antibiotika im unteren Grenzbereich mit Bac. subtilis (ATCC 6633). Fleischwirtschaft 53, 1125-1128.

[9] Mashimo, K., Fukaya, K., Kunii, O., and Suzuki, M. (1973). Studies on amoxycillin. Chemotherapy (Japan) 21, 1441-1445.

[10] Ministry of Agriculture and Forestry (1970). Minimum Requirements for Antibiotics for Animal Use. Notification No. 1883 based on the Pharmaceutical Affairs Low, Tokyo, Japan, $1-20$.

[11] Murakawa, T., Wakai, Y., Nishida, M., Fujii, R., Konno, M., Okada, K., Goto, S., and Kuwahara, S. (1970). Chromatographic assay of mixed penicillins, ampicillin and cloxacillin in body fluids. J. Antibiot. 23, 250-251.

[12] Nouws, J. F. M., van Schothorst, M., and Ziv, G. (1979). A critical evaluation of several microbiological test methods for residues of antimicrobial drugs in ruminants. Arch. Lebensm-hyg. 30, 4-8.

[13] Rollins, L. D., Mercer, H. D., Carter, G. G., and Kramer, J. (1970). Absorption, distribution, and excretion of penicillin and dihydrostreptomycin in dairy cows following intermammary infusion. J. Dairy Sci. 53, 1407- 
1414.

[14] Schmidt, U., and Cremmling, K. (1975). Untersuchungen über unspezifische Reaktionen im Hemmstofftest beim Antibiotika-Nachweis in Schweinenieren. Fleischwirtschaft 55, 17361737.

[15] Takács, J., and Kovács, S. (1969). Demonstration of antibiotic residues in the meat of slaughtered animals. Acta. Vet. Acad. Sci. Hung. 19, 11-19.

[16] Terplan, G., Barthel, G., and Zaadhof, K. J. (1974). Zum Nachweis von Hemmstoffen im Harn. Arch. Lebensm-hyg. 25, 261-264.

[17] Tittiger, F., Kingscote, B., Meldrum, B., and Prior, M. (1975). Survey of antibiotic residues in Canadian slaughter animals. Can. J. Comp. Med. Vet. Sci. 39, 178-182.

[18] Vandenbrande, G., and van Hoof, J. (1975). A comparative study of some microbiological methods for the detection of inhibitory substances in slaughter animals. Vlaams Diergeneeskd. Tijdschr. 44, 297-308.

[19] van Schothorst, M. and Peelen-Knol, G. (1970).
Detection and identification of some antibiotics in slaughter animals. Neth. J. Vet. Sci. 3, 85-93.

[20] van Schothorst, M., Uijttenboogaart, Th. G., and van Leusden, M. (1973). Über die Leistungsfähigkeit des Nierentestes bei der Bestimmung von Antibiotikarückaständen in Fleisch. Fleischwirtschaft 53, 703-705.

[21] van Schothorst, M., van Leusden, F. M., and Nouws, J. F. M. (1978). Antibiotic residues: Regulations, tolerances and detection in the European Economic Community. J. Assoc. Off. Anal. Chem. 61, 1209-1213.

[22] Wenzel, S. (1971). Allgemeiner Hemmstoffnachweis bei der Krankgeschlachteten Rindern und Schweinen und ein Vergleich mit den Hemmstoffnachweisen bei normal geschlachteten Tieren. Arch. Lebensm-hyg. 22, 200-205.

[23] Wuilleret, A. (1968). Contribution à la recherche de substances antibiotiques dans les viandes. Schweiz. Arch. Tierheilkd. 110, 523531.

動物体内におけるベンジルペニシリンとアンピシリンの鑑別法: 吉村治郎・伊藤 治・米沢昭一（農 林水産省動物医薬品検査所)——ベンジルペニシリンまたはアンピシリンを筋肉内注射した牛および豚 を用い，これらぺニシリンの鑑別を，殺処分後に採取した腎，肝，能および尿について行なった. す，蒸留水による各組織の 4 倍乳剂を作成し， pH 6.0 と 8.0 亿調整した寒天培地を用い，Micrococcus luteus ATCC 9341 および Bacillus subtilis ATCC 6633 に対する阻止径を, 平板円筒法によって 測定した．尿は，5倍希釈で 625 倍まで希釈し，同様にこれら試験菌に対する阻止径を測定した． $M$. luteus に対する阻止径が大きく，またその抗菌活性がペニシリナ一ゼの添加により消失した検体たけ を，薄層クロマトグラフィーによる鑑別に供した．次に，供試検体をメタノール処理し，3,000 rpm 10 分間遠沈した上清 $10 \mu l$ を, シリカゲルプレートの原点にスポットした. 酢酸エチル・メタノール・水 (6:2:1) で展開後，試験菌にM. luteus を用いた bioautography により Rf 值を求めた.この方法で クロマトグラム上に M. luteus の発育阻止ゾーンがみられなかった場合には，スポット量を $30 \mu l$ と して再試験を行なった。各検体とも,ベンジルペニシリンによる Rf 值はアンピシリンによるそれより も約 2 倍高く，またそれぞれの常用標準品の值ともよく一致した．以上の成績から，M. luteus 寒天培 地上の阻止径に応じて，スポット量を10ないし $30 \mu l$ とする薄層クロマトグラフ法を利用すれば，屠 畜におけるこれらペニシリンの残留の鑑別も可能と思われた. 